Revolution and the

Rebirth of Inequality 



\section{Revolution and the}

\section{Rebirth of Inequality}

\section{A Theory Applied to the National Revolution in Bolivia}

Jonathan Kelley

Herbert S. Klein 
University of California Press

Berkeley and Los Angeles, California

University of California Press, Ltd.

London, England

Copyright (C) 1981 by

The Regents of the University of California

Library of Congress Cataloging in Publication Data

Kelley, Jonathan.

Revolution and the rebirth of inequality.

Includes bibliographical references and index.

1. Revolution. 2. Equality. 3. Elite (Social

sciences) 4. Bolivia-History-Revolution, 1952.

I. Klein, Herbert S., joint author. II. Title.

HN28I.K44 984'.052 80-51239

ISBN 0-520-04072-4

Printed in the United States of America

$\begin{array}{lllllllll}1 & 2 & 3 & 4 & 5 & 6 & 7 & 8 & 9\end{array}$ 
To

J. L. Kelley père

and

Daniel Charles Klein 
